\title{
What we could do now: molecular pathology of colorectal cancer
}

\author{
R S Houlston
}

\begin{abstract}
The contribution of molecular genetics to colorectal cancer has been largely restricted to relatively rare inherited tumours and to the detection of germ line mutations predisposing to these cancers. However, much is now known about the somatic events leading to colorectal cancer in general. Several studies have examined the relation between genetic features and prognosis. The purpose of this article is to review these studies and summarise the current state of this subject. Although many of the published studies are small and inconclusive, it is clear that several different pathways exist for the development of this cancer, and some molecular characteristics seem to correlate with clinicopathological features. At present, studies are confined to evaluating a small number of molecular markers; however, with the advent of methods for the rapid genetic profiling of large numbers of colorectal cancers, it will be possible to evaluate fully the clinical usefulness of a range of colorectal cancer genotypes. (F Clin Pathol: Mol Pathol 2001;54:206-214)
\end{abstract}

Keywords: colorectal cancer; prognosis; genes

Colorectal adenocarcinoma accounts for over $90 \%$ of the malignant tumours of the large bowel. After lung and breast cancer, colorectal cancer is the most common cause of death from malignant disease in the Western world. The incidence of the disease in England and Wales is about 30000 cases/year, ${ }^{1}$ resulting in approximately 17000 deaths/annum, ${ }^{2}$ and it has been estimated that at least half a million cases of colorectal cancer occur each year world wide. ${ }^{3}$ Incidence rates of colorectal cancer are increasing in many countries. Unfortunately, despite improvements in medical and surgical provision, there has been comparatively little change in mortality from colorectal cancer during the past 40 years, ${ }^{4}$ and the overall five year survival is only around $40 \%$.

\section{Natural history of colorectal cancer}

Section of Cancer Genetics, Institute of Cancer Research, Sutton, Surrey SM2 5NG, UK R S Houlston

Correspondence to: Dr Houlston

r.houlston@icr.ac.uk

Accepted for publication 15 March 2001
In Western countries, approximately $60 \%$ of primary colorectal cancers are situated in either the rectum or sigmoid. Of the remainder, a half arise within the caecum. Colorectal cancers are generally staged according to Dukes's system into categories A, B, C, and D. ${ }^{5}$ Grade can be either expressed simply as degree of differentiation (well, medium, or poorly differentiated) or according to the more complex Jass grouping. ${ }^{6}$ Prognosis correlates extremely well with both stage and grade.
Patients with colorectal cancer fall broadly into two groups at time of presentation. The first group has either non-resectable or disseminated disease. These patients have a very poor prognosis, with a median survival of seven months. ${ }^{3}$ The other two thirds of patients will undergo a resection of their primary tumour. Despite an apparently "curative" resection, approximately $50 \%$ of patients die within five years, and of these around $80 \%$ will have had a detectable recurrence within two years. Most of these patients die as a result of liver metastases, but there is evidence that they also have extensive extrahepatic disease. Studies of occult hepatic metastases have estimated that the mean age of deposits at time of surgery is 18 months. ${ }^{7}$ This suggests that many colorectal cancers metastasise early, but that some tumours cannot or do not metastasise, and that the factors that determine the propensity to metastasise may have acted before presentation. Improved success in the treatment of colorectal cancer clearly requires a better understanding of its development and behaviour. Molecular studies have shown that the natural history of all colorectal cancers is not identical. The molecular basis of the clinicopathological features of some tumours has been determined. If genotypic markers could be identified that correlate with tumour behaviour and patient prognosis, this should lead to a more accurate prediction of prognosis and tailoring of treatment.

\section{Molecular genetics of colorectal cancer} THE ADENOMA-CARCINOMA SEQUENCE

Histological observations led to the concept that most colorectal cancers develop from normal epithelium through sequentially worsening degrees of adenomatous dysplasia. ${ }^{8}$ The genetic pathway model for the pathogenesis of sporadic colorectal cancer proposed by Fearon and Vogelstein is based upon this concept of an adenoma to carcinoma sequence (fig 1). ${ }^{9}$ Although the total accumulation of mutations is the principal factor, the model proposed that the causative mutations in tumour suppressor genes and oncogenes occur in a specific order in most colorectal cancers (specifically, adenomatous polyposis coli (APC) gene mutations, global hypomethylation, K-ras mutations, deleted in colon cancer (DCC) gene mutations, and finally mutations in the p53 gene). The Fearon and Vogelstein model of colorectal carcinogenesis was proposed over 10 years ago. During this time, other mutations that occur at a high frequency in colorectal cancer have been identified, and the original model can be considerably elaborated to take in account the 


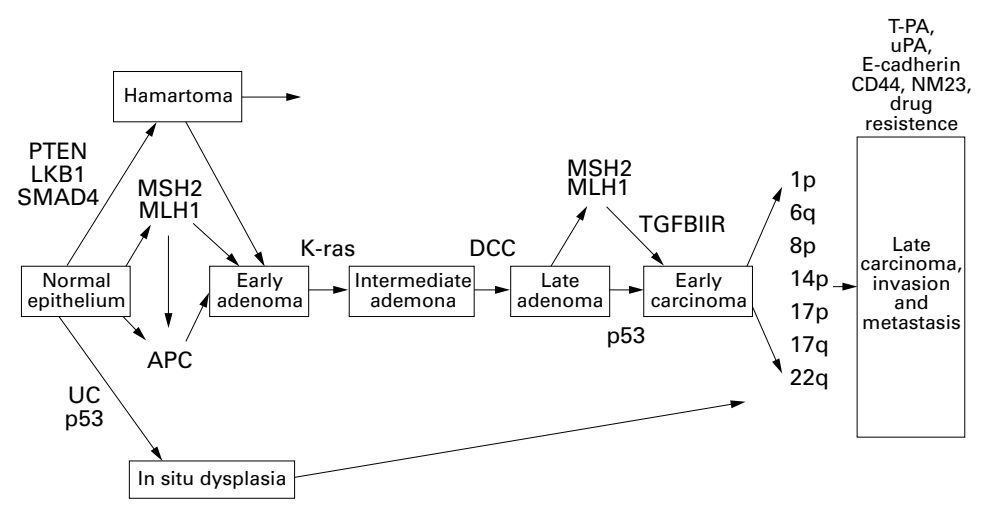

Figure 1 Genetic pathways of colorectal carcinogenesis.

alternative pathways for the development of cancer that are now known to exist.

INITIATION OF COLORECTAL CARCINOGENESIS There is good evidence that only two mutations are required for the initiation of colorectal carcinogenesis. In most cases, these mutations occur at the APC tumour suppressor locus (5q21-q22). ${ }^{10-12}$ APC mutations, which generally lead to a truncated APC protein, ${ }^{13}$ or take the form of allele loss, ${ }^{14}$ are detected in about $75 \%$ of sporadic colorectal cancers ${ }^{15}$ and are observed in the earliest adenomas. ${ }^{10}$ In addition to the role of the APC gene in the aetiology of sporadic colorectal cancer, germline mutations in this gene cause familial adenomatous polyposis coli (FAP), which is characterised by florid adenomas within the gastrointestinal tract. The APC protein acts as a dimer. ${ }^{16}$ It is likely that the gene product exerts its tumour suppressor actions through intracellular signalling, interactions with the cytoskeleton, and the control of cellular proliferation, possibly by affecting the rate of cell division or apoptosis. ${ }^{17-22}$

Whether APC mutations are always the first events in colorectal carcinogenesis or whether germline defects in one of the mismatch repair (MMR) genes could provide an alternative initiating step has been questioned. Mutations in three MMR genes primarily cause the dominantly inherited syndrome hereditary nonpolyposis colorectal cancer (HNPCC): $\mathrm{MSH} 2$ on chromosome $2 \mathrm{p}, \mathrm{MLH} 1$ on chromosome $3 \mathrm{p}$, and MSH6 on chromosome $2 \mathrm{p} 16^{23-26}$ Colorectal cancers from patients with mutations in these MMR genes consistently show microsatellite instability (MSI), a form of replication error (RER). Although it is generally assumed that mutations in the MMR genes in HNPCC families act only to increase the mutation rate (including mutations in APC), it is also possible that the MMR mutations themselves have a direct role in initiation. MMR mutations also occur in sporadic coloectal cancers $^{27}$; however, when these mutations arise somatically they occur after APC mutations and are therefore involved in the progression of tumours rather than initiation. ${ }^{28}$

Colorectal cancers associated with ulcerative colitis do not usually develop from adenomas, ${ }^{29}$ suggesting a different genetic pathway from sporadic cancers. ${ }^{30}$ The low frequency of APC mutations in inflammatory bowel disease associated cancers suggests that mutations in this gene are not the initiating event in these tumour types. ${ }^{31-33}$

The possibility that mutations in genes other than APC can initiate colorectal tumorigenesis is suggested by reports of adenoma families unlinked to APC. ${ }^{34}$ In addition, there is emerging evidence that a hamartoma-adenomacarcinoma sequence exists, ${ }^{35}$ and genes for several hamartoma syndromes have been identified (such as Peutz Jeghers syndrome caused by LKB1 mutations, ${ }^{36}$ some forms of juvenile polyposis caused by SMAD4 mutations, ${ }^{37}$ and Cowden's syndrome caused by PTEN mutations ${ }^{38}$ ). Furthermore, there is some support for a hyperplastic polyp adenoma carcinoma sequence (fig 1 ). ${ }^{39}$

COLORECTAL CANCER PROGRESSION: EARLY ADENOMA TO CARCINOMA

Although mutations in the APC gene are initiating events in colorectal tumorigenesis, these mutations alone are probably insufficient for adenomas to progress, and without mutations at other loci regression might occur. ${ }^{40}{ }^{41}$ Several genes are involved in the progression of early adenomas to early carcinomas. Early candidates for adenoma progression were the ras oncogenes. The K-ras gene is one of a family of three human ras genes (K-ras, H-ras, and $\mathrm{N}$-ras). ${ }^{42}$ These encode small GTP binding proteins localised to the inner leaflet of the cell membrane and are involved in transducing signals from receptor tyrosine kinases such as epidermal growth factor receptor (EGFR). The receptors are coupled to the ras proteins through an intermediate complex of GRB and SOS2 proteins. Downstream elements of this transduction pathway include the cytoplasmic RAF serine threonine kinase and mitogen activated protein (MAP) kinase cascade. The ras proteins are activated on binding GTP and deactivated by intrinsic GTPase activity from two GTPase activating (GAP) proteins. One of these is ras-GAP-p120 and the other neurofibromin, the product of the NF1 gene. The ras oncogenes are activated by point mutations that prevent the activation of GTPase. ${ }^{42}$ More than $50 \%$ of colorectal cancers display specific mutations in the K-ras gene, with an increasing frequency in larger and more advanced lesions. ${ }^{43}$ The consequence of K-ras mutations during tumour development may be a growth advantage of those cells with both APC and K-ras mutations over cells with APC mutations alone. Whereas K-ras mutations are seen within histologically normal mucosa, ${ }^{44}$ they appear only to be present in dysplastic mucosa with coexisting APC mutations. ${ }^{45} 46$ This supports the notion that K-ras mutations confer no growth advantage in the absence of a mutation in the APC gene.

The MCC (mutated in colon cancer) and DCC tumour suppressor genes were originally thought to play a role in colorectal carcinogenesis. In the model of Fearon and Vogelstein, mutation at the DCC locus represented the third step in the genetic pathway. ${ }^{9}$ The MCC 
and DCC genes were identified as a result of the frequent allele loss close to their locations on $5 \mathrm{q} 21-\mathrm{q} 22$ and $18 \mathrm{q} 21.3$, respectively, in colorectal cancers. ${ }^{47} 48$ A small number of mutations at MCC were originally described in colorectal cancers, ${ }^{49}$ but subsequent studies have found very few mutations, suggesting that APC is the primary target for allele loss on $5 \mathrm{q} 21-\mathrm{q} 22 .^{50}$ DCC is a neural cell adhesion molecule homologue and DCC mutations may therefore have a role in colorectal tumour progression, invasion, and metastasis (although allele loss at DCC generally occurs before malignancy). However, there is evidence suggesting that SMAD4 may also be the target of allele loss on chromosome $18 \mathrm{q}$ in some cancers. $^{51}$

There is no doubt about the role of p53 mutations in the progression of colorectal tumours. The p53 protein is important in maintaining DNA integrity. DNA damage results in p53 mediated arrest in G1 phase of the cell cycle, followed by repair or, if the damage is too great, p53 induced apoptosis. Therefore, loss of function of $\mathrm{p} 53$ by mutation or deletion allows cells to accumulate mutations throughout the genome and results in karyotypic instability, impaired G1 cell cycle arrest, and reduced apoptosis. ${ }^{52-55}$ Mutations in the p53 gene occur in around $75 \%$ of colorectal cancers, but the frequency is lower in mucinous cancers and those that arise in the proximal colon, as seen in HNPCC. p53 mutations are rare in adenomas, suggesting that $\mathrm{p} 53$ plays a role in tumour progression, but it is not an absolute requirement for malignant transformation because a large proportion of cases have no demonstrable abnormality. p53 mutations tend to occur at the late adenoma stage (although earlier in inflammatory bowel disease associated colorectal cancers, which do not develop from adenomas).$^{56}$ Dominant, gain of function mutations in p53 are common in colorectal cancers, and these can be detected reliably using immunohistochemistry for the p53 protein. ${ }^{57} 58$ Allele loss near p53 (chromosome $17 \mathrm{p} 13.1)$ also occurs frequently, ${ }^{56}$ either because of loss of the wild-type allele or possibly because another gene nearby is targeted.

The sites of other candidate tumour suppressor genes that might be involved in colorectal tumour progression have been identified by allele loss studies. Mutations of the FHIT gene $^{59}$ and at the p16 (MTS1) locus ${ }^{60-62}$ may be important in colorectal tumours, the latter through failure of cell cycle arrest. Locations of other tumour suppressor loci include chromosomes $1 \mathrm{p}$ (near the putative human Mom-1 homologue), ${ }^{6364} 6 \mathrm{q},{ }^{65} 8 \mathrm{p},{ }^{66} 6714 \mathrm{q},{ }^{68}$ and $22 \mathrm{q} .{ }^{69}$ Allele loss typically occurs at these locations at frequencies of between $30 \%$ and $60 \%$.

The roles of MMR mutations in colorectal tumorigenesis have been discussed briefly. In HNPCC tumours, one mutation is inherited and the other occurs somatically; in about $15 \%$ of sporadic colon cancers, two MMR mutations (or two mutations at a related locus) occur in the soma. ${ }^{70}$ Normal mucosa from patients with HNPCC does not display MSI; only $50 \%$ of HNPCC adenomas (compared with $90 \%$ of cancers) exhibit MSI, and the frequency of early lesions such as APC mutations is similar in MSI and MSS (microsatellite stable) tumours. ${ }^{71} 72$ Therefore, in sporadic cancers, defective MMR function might be an alternative method to allele loss of acquiring mutations, and loss of MMR may simply "catalyse" the progress of a tumour down the same pathway as MSS cases. It is possible that MMR mutations act as alternatives to p53 mutations in colorectal tumours, albeit through a different mechanism. Whereas genomic instability in p53 mutant cancers tends to take the form of karyotypic abnormalities, instability resulting from MMR mutations leads to near diploid lesions. It has been found that MMR mutations are negatively associated with mutant p53 and that, like p53 mutations, MMR mutations often occur in late colonic adenomas. ${ }^{72}{ }^{73}$ Genomic instability may also be caused by somatic or germline mutations in other genes involved in DNA replication and repair. There is support for this from a study of two apparently sporadic colorectal cancer cases that harboured DNA polymerase $\delta$ variants. ${ }^{74}$

MALIGNANCY

Few genetic changes specific to mature colorectal cancers have been identified. Several regions of allele loss have been detected, but their roles in tumour progression are unclear. The types of mutations that will be important in mature colorectal cancer are those that cause faster replication, decreased apoptosis, or angiogenesis. Malignancy requires colorectal tumour cells to exhibit several features, namely: (1) the ability to erode the basement membrane; (2) the ability to disrupt normal cell junctions; and (3) the capacity to survive in the blood or lymphatic systems and in a new tissue environment.

Cell adhesion molecules are candidates for involvement in the process of invasion and metastasis of colorectal cancers. Mutations at these loci may have effects on growth, in addition to those on adhesion. For example, E cadherin forms part of the adherens junction complex of epithelial cells. Loss of E cadherin protein occurs in several cancers, including colorectal cancer, and is associated with the development of invasive properties. ${ }^{75-77}$ Other proteins that may be associated with invasion of colorectal cancers include those involved in tissue degradation, such as urokinase plasminogen activators and matrix metalloproteinases/ collagenases. ${ }^{78}$ The cells of metastases may have genotypes and/or patterns of gene expression distinct from primary tumours. Variation at several gene loci may alter the behaviour pattern of the mature colorectal cancer. These include the NM23 gene, which has a possible role in the metastasis of several cancers, and CD $44 .^{80-85}$

\section{Clinicopathological correlations: prediction of prognosis}

The recognition that there are probably several different genetic pathways for colorectal cancer suggests that correlations exist between the 
molecular and clinicopathogical features of tumours that are not apparent using routine methods such as histology. These correlations may serve as prognostic determinants and/or enable the partitioning of patients with colorectal cancer into groups for different treatments. Several studies have sought to examine the relation between genotypic variation in colorectal cancers and clinicopathological features, especially prognosis. Most work has been in the form of case control studies using a comparison of the frequency of genotypes in primary and secondary tumours as a surrogate for survival. However, a small number of studies have examined the relation between genotype and prognosis by classic survival analysis. In this section, the evidence for genetic variation in colorectal cancers as markers of prognosis is reviewed, including some studies of protein or mRNA expression that have been assumed to be indicators of underlying mutations.

ALLELE LOSS STUDIES

In an early allelotyping study based upon 56 patients with colorectal cancer, Vogelstein et al showed that patients with more than the median percentage of allelic deletions had a worse prognosis. ${ }^{86}$ Later studies have examined the relation between specific chromosome abnormalities and tumour behaviour.

Chromosome 18q loss has been evaluated extensively as a prognostic marker in several studies. ${ }^{47}{ }^{87-93}$ In a study of 145 patients with resected stage II or stage III disease reported by Jen et $a l,{ }^{47}$ the five year survival rate was $93 \%$ in those with no loss and $54 \%$ in those with chromosome 18q loss in stage II disease, and 52\% and $38 \%$, respectively, with stage III disease. The overall estimated hazard ratio (HR) for death associated with tumour chromosome $18 \mathrm{q}$ loss was $2.8(\mathrm{p}<0.01)$ in a univariate analysis. Allelic loss remained a strong predictive factor after adjustment for tumour differentiation, vein invasion, and TNM stage $(\mathrm{HR}=2.46 ; 95 \%$ confidence interval $(\mathrm{CI})$, 1.06 to $5.71 ; \mathrm{p}=0.04)$. A similar finding was reported by Ogunbiyi et al from an analysis of 151 patients who had undergone potentially curative surgery for colonic disease. ${ }^{91}$ Chromosome $18 \mathrm{q}$ allelic loss was a negative prognostic indicator of both disease free $(\mathrm{HR}=1.65$; $\mathrm{p}=0.01)$ and disease specific survival $(\mathrm{HR}=2.0 ; \mathrm{p}=0.003)$. Furthermore, $18 \mathrm{q}$ loss was associated with significantly reduced disease free and disease specific survival in cases with stage II ( $p=0.05$ and $p=0.016)$ and III ( $p=0.038$ and $p=0.032$ ) disease. Two studies have specifically examined the relation between $18 \mathrm{q}$ allele loss and prognosis in stage II disease..$^{92}{ }^{93}$ The study reported by MartinezLopez et al based on 144 patients supported the notion that allele loss in tumours is associated with an unfavourable outcome. ${ }^{93}$ Five year survival was $42 \%$ in those with chromosome $18 \mathrm{q}$ loss and $73 \%$ in those without detectable loss $(p<0.01)$. Multivariate analysis showed that tumour site $(\mathrm{p}<0.001)$ and $18 \mathrm{q}$ loss ( $p=0.01)$ were the only independent prognostic factors. Furthermore, loss had a significant influence on survival $(p=0.016)$. In contrast, the study reported by Carethers et $a l,{ }^{92}$ based on 70 patients, found that $18 \mathrm{q}$ allelic loss was not associated with a survival disadvantage $(\mathrm{HR}=1.17 ; 95 \% \mathrm{CI}, 0.27$ to 5.10$)$.

Cytogenetic and allele loss studies of chromosome 17 (and in particular at the NM23 locus) have been based on fewer patients than the analyses of chromosome 18q. ${ }^{87-96}$ Most studies have found that both $17 \mathrm{p}$ and $17 \mathrm{q}$ anomalies are associated with invasion and metastasis, and allele loss at $17 \mathrm{q}$ has been proposed to provide independent prognostic information. ${ }^{95}$

Mutations that are likely to have prognostic relevance are those that occur in genes involved in tumour progression rather than initiation. Therefore, it is not surprising that allele loss at chromosome 5q, the site of the APC gene, has not been shown to have prognostic value. ${ }^{87} 8890$ The high rate of allele loss in other chromosomes such as $8 \mathrm{p}, 1 \mathrm{p}$, and $11 \mathrm{q}$ during tumour progression suggests that these may be sites of other tumour suppressor genes important for the progression of colon tumours. A correlation between $8 \mathrm{p}$ allele loss and microinvasion (a prognostic marker independent of Dukes's stage) has been reported in one small study of 14 patients with cancer. ${ }^{97} \mathrm{~A}$ relation between tumour progression and chromosome 1 deletions has also been shown in one study of 116 patients who had undergone curative treatment $(\mathrm{HR}=4.1 ; 95 \% \mathrm{CI}, 1.25$ to 9.23$) .{ }^{98}$

Allele loss at other chromosomes has been evaluated less extensively. An analysis of 126 sporadic colorectal cancers for allele loss at chromosome 11q22 failed to show a relation with Dukes's grade or degree of differentiation..$^{99}$ A prospective study assessing allelic loss at chromosome $4 \mathrm{p} 14-16$ in 181 patients has suggested that allele loss may be associated with a shorter disease free survival. ${ }^{100}$

K-RAS

Along with p53, K-ras mutations are one of the most common genetic lesions in human cancer. Since the discovery of the human ras gene family, the effect of different ras mutations on tumour behaviour have been debated. Point mutations in codons 12, 13, and 61 of the $\mathrm{K}$-ras gene are early events in the pathogenesis of colorectal cancer. However, the impact of the number, type, and position of such mutations on the progression of adenomas, in addition to the clinical behaviour of colorectal carcinomas, is not fully established. To date, most studies have indicated that the second base of codon 12 is more heavily mutated in colorectal cancer than the first or the third bases. Therefore, it is conceivable that the type of K-ras mutation directly determines tumour behaviour.

In a study of 194 consecutive primary, recurrent, and metastatic colorectal adenocarcinomas, Finkelstein et al reported a significantly higher mutation rate of K-ras mutations in lymphogenous haematogenous metastatic disease. ${ }^{101}$ When colorectal carcinomas were analysed by specific K-ras mutation type, codon 13 mutated tumours did not progress locally or metastasise. Tumours with a codon 
12 valine substitution did not metastasise beyond pericolonic perirectal lymph nodes. In contrast, codon 12 aspartic acid substitutions were common in cancers exhibiting distant deposits. No mutations were common in tumours with intraperitoneal deposits. On the basis of these data, Finkelstein et al proposed that genotyping of colorectal adenocarcinoma for K-ras status would identify subsets of patients likely to have indolent or aggressive forms of disease. ${ }^{101}$ Some, but not all, reports have supported the proposal that the possession of a K-ras mutation is independently associated with shorter survival. ${ }^{102-106}$ To clarify the association between K-ras mutations, patient outcome, and tumour characteristics a metaanalysis of data from 22 research groups (total number of cases 2721) was undertaken by Andreyev et al. $^{107}$ Mutations were not associated with sex, age, site, or stage. Poorly differentiated tumours were less frequently mutated $(p=0.002)$. Multivariate analysis suggested that the presence of a mutation increased risk of recurrence $(p<0.001)$ and death $(\mathrm{p}=0.004)$. In particular, any mutation of guanine to thymine but not to adenine or to cytosine increased the risk of recurrence $(p=0.006)$ and death $(p<0.001)$. When specific mutations were evaluated, only the codon 12 valine mutation was found to convey an independent, increased risk of recurrence $(p=0.007)$ and death $(p=0.004)$. The biological basis of a relation between a specific K-ras mutation and tumour behaviour is not straightforward. Early in vitro observations suggested that codon $12 \mathrm{~K}$-ras mutations elicited stronger transformation responses than codon $13 \mathrm{~K}$-ras changes in NIH/3T3 cell assays. ${ }^{108-110}$ However, this notion has not been supported by biochemical analyses of different ras proteins. ${ }^{11-113}$ On the basis of the available clinicopathological data, it is likely that patient survival is related to the occurrence of K-ras mutations, but not necessarily to the specific type of mutation.

DCC

If allele loss of chromosome $18 \mathrm{q}$ predicts a poor outcome in colorectal cancer, then the DCC gene must represent a prime candidate as the cause for this association. In a study of 132 patients with curatively resected stage II and III carcinomas, the expression of the DCC protein has been shown to be a strong positive predictive factor for survival. ${ }^{114}$ Patients with stage II disease whose tumours expressed DCC had a five year survival rate of $94 \%$, compared with a survival rate of $62 \%$ for patients with DCC negative tumours. Similarly, in individuals with stage III disease, the respective survival rates were $59 \%$ and $33 \%$ in those with and without detectable DCC expression. This finding has been supported by a recently published small study of 23 patients. ${ }^{115}$

MISMATCH REPAIR GENES AND MICROSATELLITE INSTABILITY

Evidence directly correlating molecular and clinicopathological data for colorectal cancer has come from HNPCC. Colorectal cancers developing in carriers of HNPCC mutations are poorly differentiated and frequently multiple. Paradoxically, despite multiplicity and poor differentiation of cancers, early observations suggested that colorectal cancers in HNPCC carried a more favourable prognosis that in sporadic cases. Convincing evidence for improved survival in HNPCC is provided by studies from Finland ${ }^{116}$ and Japan. ${ }^{117}$

Whether MSI characterises a subset of sporadic colorectal cancers with a different prognosis has been evaluated in several studies. One of the early studies reported by Bubb et al in 1996 was based on a systematic analysis of 215 sporadic cases. ${ }^{118}$ Patients with MSI tumours had a significant survival advantage over those with MSS tumours, independent of other prognostic factors $(\mathrm{HR}=0.39 ; 95 \% \mathrm{CI}$, 0.19 to 0.82 ). Several subsequent studies have reinforced this finding. In a study of 66 cases, Massa et al found that MSI status was independently associated with an improved prognosis (defined by overall survival and disease free survival). ${ }^{119}$ A large study based on 607 patients reported by Gryfe et al also found that MSI status conferred a significant survival advantage, independent of all standard prognostic factors, including tumour stage $(\mathrm{HR}=0.42$; 95\% CI, 0.27 to 0.67$) .{ }^{120}$ Regardless of the depth of tumour invasion, colorectal cancers with MSI had a decreased likelihood of metastasising to regional lymph nodes $(\mathrm{HR}=0.33 ; 95 \% \mathrm{CI}, 0.21$ to 0.53$)$ or distant organs $(\mathrm{HR}=0.49 ; 95 \%, 0.29$ to 0.89$)$. A similar relation was seen between MSI status and prognosis in a study of 197 patients reported by Johannsdottir et al. ${ }^{121}$ Although MSI was not associated with clinicopathological parameters, such as Dukes's stage and tumour differentiation, this phenotype was associated with better overall survival. From an analysis of 225 colorectal cancer cases, Jernvall et al found that the five year survival rate in MSI cancers of the proximal colon was much better $(100 \%)$ than that of those with MSS proximal disease $(74 \%) .{ }^{122}$ However, an opposite effect was seen in relation to distal disease. In a study of a consecutive series of 388 Dukes's C colon carcinomas with five year median follow up reported by Elsaleh et al, ${ }^{123}$ the presence of MSI in the proximal transverse colon carcinoma group was associated with a significantly better prognosis (58\% v 32\%; $p=0.015)$. This was largely the result of the better survival seen in the MSI subgroup that received adjuvant chemotherapy, leading to the proposal that MSI status might determine the response to adjuvant chemotherapy. However, this seems unlikely to be the sole explanation of a better prognosis. Wright et al found MSI status conferred a significant survival advantage in patients who had not been in receipt of chemotherapy. ${ }^{124}$ Furthermore, Hemminki et al found that adjuvant 5-FU based chemotherapy is feasible both for patients with MSI and those with MSS. ${ }^{125}$ The three year recurrence free survivals were $90 \%$ and $43 \%$ in the MSI and MSS groups, respectively. Although most studies have found a relation between MSI status and prognosis some have not, including a report by 
Salahshor et al, ${ }^{126}$ based on a survival analysis at five to 10 years follow up of 181 unselected colorectal cases. Given that only approximately $15 \%$ of cancers display MSI, failure to demonstate a difference might be the result of a lack of power in this study.

Overall, the weight of evidence supports the tenant that although the genetic basis of HNPCC and sporadic cancers with MSI is different, tumours in the two groups share some biological characteristics in terms of prognosis. MSI in colorectal cancer appears to be an independent predictor of a relatively favourable outcome and, in addition, reduces the likelihood of metastases.

p53 AND p27

An increased intracellular concentration of p53, which is frequently but not systematically related to $\mathrm{p} 53$ mutation, has been proposed to be associated with poor prognosis in some tumour types. In colorectal cancer, although p53 overexpression in tumours correlates with chromosome $17 \mathrm{p}$ loss, hyperdiploid DNA content, and tumour site, there have been conflicting findings about its role as a prognostic indicator in studies based on immunohistochemistry. ${ }^{127-140}$ This reflects the fact that the degree of association between p53 mutations and protein expression depends in part on the specific antibody used. In studies of the relation between $\mathrm{p} 53$ mutations and prognosis, the situation is clearer. Studies suggest that colorectal cancers harbouring p53 mutations are more aggressive, are associated with a higher propensity for lymphatic and haematogenous spread, and have a worse prognosis. ${ }^{141-147}$ However, this is not universal. ${ }^{123}$

p27 is a member of the cip/kip family of cyclin dependent kinase inhibitors, which bind to cyclin:cyclin dependent kinase (cdk) complexes and block progression through the cell cycle. 27 regulates progression from $\mathrm{G} 1$ into $\mathrm{S}$ phase by binding to and inhibiting the cyclin $\mathrm{E} / \mathrm{Cdk} 2$ complex, which is required for cells to enter $\mathrm{S}$ phase. In contrast to the p53 gene, mutations in p 27 are rare. However, cell cycle regulation of $\mathrm{p} 27$ concentrations are regulated at the post transcriptional level through proteasome mediated degradation. ${ }^{148}$ Reduced expression of p27 was first shown to correlate with poor survival in a study of 149 patients reported by Loda et al. ${ }^{149}$ Patients whose tumours expressed p27 had a median survival of 151 months, whereas those that lacked p27 $(10 \%)$ had a median survival of only 69 months. In the study, p27 expression was reported to be an independent prognostic marker and the risk of death associated with reduced expression was increased 2.9-fold. Subsequent studies have confirmed that p27 appears to have prognostic importance. ${ }^{150-152}$ Furthermore, decreased p27 expression has been associated with an increased likelihood of lymph node metastases in colon cancers, independent of depth of tumour invasion. ${ }^{151}$

\section{Conclusions}

The incidence of colorectal cancer is increasing and unfortunately the prognosis remains poor for most patients. The identification of those patients who are at a high risk of recurrent local and metastatic disease is important in selecting the appropriate treatment. Prognostic variables that have been found to have a significant effect include pathological stage and grade, type of tumour growth, chromosomal aneuploidy, and the presence of microinvasion. Until recently, there has been little understanding of the molecular basis of these indices. Despite the continuing use of histopathology as the "gold standard", the genetic features of colorectal tumours will almost certainly become useful indicators of prognosis and of the most appropriate treatment. One of the problems with clinicomolecular associations reported to date has been that most studies have, for entirely understandable reasons, analysed only small numbers of tumours. Publication bias is a serious problem in assessing the usefulness of any given marker because positive associations have a far higher probability of being published than negative ones. Contradictory results between studies may reflect in part heterogeneity in colorectal cancers. It has been suggested that multiple biopsies and DNA sampling preceded by careful morphological examination must be standard if the preparation of DNA is required..$^{153}$

Accepting these caveats, there is evidence that colorectal cancers harbouring defects in the MMR genes are associated with a better prognosis and those with chromosome anomalies, such as chromosome $18 \mathrm{q}$ or 17 deletions and mutations in K-ras and p53, with a worse prognosis. With the advent of methods for rapid genotyping it should be possible to construct mutation profiles of tumours and use multivariate analysis to determine which molecular features correlate with the clinicopathological data.

1 Office of National Statistics. Cancer Statistics. Registrations. England and Wales. London: HMSO, 1989.

2 Office of National Statistics. Mortality statistics. Cause. England and Wales. London: HMSO, 1992.

3 Finlay IG, Pickford IR. Colorectal carcinoma. In: Lawson $\mathrm{DH}$, ed. Current medicine, 4th ed. Edinburgh: Churchill Livingstone, 1994:51-64.

4 Beart RW, Steele GJ, Menck HR, et al. Management and survival of patients with adenocarcinoma of the colon and rectum: a national survey of the commission on cancer. $\mathcal{F}$ Am Coll Surg 1995;181:225-36.

5 Dukes CE, Bussey HJR. The spread of cancer and its effect on prognosis. Cancer 1958;12:309-20.

6 Jass JR, Love SB, Northover JMA. A new prognostic classification of rectal cancer. Lancet 1987;ii:1303-6.

7 Finlay IG, Meck D, Bruton F, et al. Growth rate of hepatic Finlay IG, Meck D, Bruton F, et al. Growth rate of hepatic
metastases in colorectal cancer. Br f Surg 1988;75:641-4 metastases in colorectal cancer. Br f Surg 1988;75:641-4.
8 Morson B, Dawson I, Day D, et al. Morson and Dazwson's gastrointestinal pathology, 3rd ed. Oxford: Blackwell Sciengastrointestinal pathology,
tific Publications, 1997 .

9 Fearon ER, Vogelstein B. A genetic model for colorectal tumorigenesis. Cell 1990;61:759-67.

10 10. Powell SM, Zilz N, Beazer Barclay Y, et al. APC mutations occur early during colorectal tumorigenesis. Nature 1992;359:235-7.

11 Groden J, Thliveris A, Samowitz W, et al. Identification and characterization of the familial adenomatous polyposis coli gene. Cell 1991;66:589-600.

12 Kinzler KW, Nilbert MC, Su LK, et al. Identification of FAP locus genes from chromosome 5q21. Science 1991;253: $661-5$.

13 Miyoshi Y, Nagase H, Ando H, et al. Somatic mutations of the APC gene in colorectal tumors: mutation cluster region in the APC gene. Hum Mol Genet 1992;1:229-33.

14 Solomon E, Voss R, Hall V, et al. Chromosome 5 allele loss in human colorectal carcinomas. Nature 1987;328:616-19.

15 Miyaki M, Konishsi M, Kikuchi Yanoshita R, et al. Characteristics of somatic mutation of the adenomatous polyposis coli gene in colorectal tumours. Cancer Res 1994;54:301120 . 
16 Joslyn G, Richardson DS, White R, et al. Dimer formation by an N terminal coiled coil in the APC protein. Proc Nat by an $N$ terminal coiled coil in the
Acad Sci U S A 1993;90:11109-13.

17 Baeg GH, Matsumine A, Kuroda T, et al. The tumour suppressor gene product APC blocks cell cycle progression from $\mathrm{G} 0 / \mathrm{G} 1$ to $\mathrm{S}$ phase. $E M B O \mathcal{F} 1995 ; \mathbf{1 4}: 5618-25$.

18 Su LK, Vogelstein B, Kinzler KW. Association of the APC tumor suppressor protein with catenins. Science 1993;262: 1734-7.

19 Rubinfeld B, Souza B, Albert I, et al. Association of the APC gene product with beta catenin. Science 1993;262:1731-4.

20 Browne S, Williams A, Hague A, et al. Loss of apc protein expressed by human colonic epithelial cells and the appearance of a specific low molecular weight form is assoc with apoptosis in vitro. Int $\mathcal{f}$ Cancer 1994;59:56-64.

21 Burchill SA. The tumour suppressor APC product is associated with cell adhesion. Bioessays 1994;16:225-7

22 Munemitsu S, Souza B, Muller O, et al. The APC gene product associates with microtubules in vivo and promotes their assembly in vitro. Cancer Res 1994;54:3676-81.

23 Leach FS, Nicolaides NC, Papadopoulos N, et al. Mutations of a mutS homolog in hereditary nonpolyposis colorectal cancer. Cell 1993;75:1215-25.

24 Fishel R, Lescoe MK, Rao MR, et al. The human mutator gene homolog MSH2 and its association with hereditary nonpolyposis colon cancer. Cell 1993;75:1027-38.

25 Aaltonen LA, Peltomaki P, Leach FS, et al. Clues to the pathogenesis of familial colorectal cancer. Science 1993, 260:812-16.

26 Kolodner RD, Tytell JD, Schmeits JL, et al. Germ-line msh6 mutations in colorectal cancer families. Cancer Res 1999;59:5068-74

27 Liu B, Nicolaides NC, Markowitz S, et al. Mismatch repair gene defects in sporadic colorectal cancers with microsatellite instability. Nat Genet 1995;9:48-55.

28 Tomlinson IPM, Novelli MR, Bodmer WF. The mutation rate and cancer. Proc Natl Acad Sci U S A 1996;93:148003

29 Connell WR, Talbot IC, Harpaz N, et al. Clinicopathological characteristics of colorectal carcinoma complicating ulcerative colitis. Gut 1994;35:1419-23.

30 Ilyas M, Tomlinson IPM. Genetic pathways in colorectal cancer. Histopathology 1996;28:389-99.

31 Redston M, Papadopoulos N, Caldas C, et al. Common occurrence of APC and $\mathrm{K}$ ras mutation in the spectrum of colitis associated neoplasias. Gastroenterology 1995;108: 383-92.

32 Tarmin L, Yin J, Harpaz N, et al. Adenomatous polyposis coli gene mutations in ulcerative colitis associated dysplasias and cancers versus sporadic colon neoplasms. Cancer Res 1995;55:2035-8.

33 Brentnall TA, Crispin DA, Rabinovitch PS, et al. Mutations in the p 53 gene: an early marker of neoplastic progression in the p53 gene: an early marker of neoplastic progres

34 Tops CM, van der Klift HM, van der Luijt RB, et al. Non allelic heterogeneity of familial adenomatous polyposis. $\mathrm{Am}$ f Med Genet 1993;47:563-7.

35 Whitelaw SC, Murday VA, Tomlinson IPM, et al. Clinical and molecular features of the hereditary mixed polyposis syndrome. Gastroenterology 1997;112:327-34

36 Hemminki A, Markie D, Tomlinson I, et al. A serine/ threonine kinase gene defective in Peutz-Jeghers syndrome. Nature 1998;391:184-7.

37 Howe JR, Roth S, Ringold JC, et al. Mutations in the SMAD4/DPC4 gene in juvenile polyposis. Science 1998; 280:1086-8.

38 Liaw D, Marsh DJ, Li J, et al. Germline mutations of the PTEN gene in Cowden disease, an inherited breast and thyroid cancer syndrome. Nat Genet 1997;16:64-7.

39 Jeevarathnam P, Cottier DS, Browett PJ, et al. Familial giant hyperplastic polyposis predisposing to colorectal cancer a new hereditary bowel cancer syndrome. $\mathcal{F}$ Pathol 1996;179: $20-5$.

40 Shepherd JA. Regression phenomenon in familial polyposis. Proc R Soc Med 1972;65:169.

41 Giardello FM. Sulindac and polyp regression. Cancer Metastasis Rev 1994;13:279-83.

42 Bos JL. The ras gene family and human carcinogenesis. Mutat Res 1988;195:255-71.

43 Smith AJ, Stern HS, Penner M, et al. Somatic APC and K ras codon 12 mutations in aberrant crypt foci from human colons. Cancer Res 1994;54:5527-30.

44 Minamoto T, Yamashita N, Ochiai A, et al. Mutant $\mathrm{K}$ ras in apparently normal mucosa of colorectal cancer patients. Its potential as a biomarker of colorectal tumorigenesis. Cancer potential as a biomarker of

45 Pretlow TP. Aberrant crypt foci and $\mathrm{K}$ ras mutations: earliest recognised players or innocent bystanders in colon carcinogenesis? Gastroenterology 1995;108:600-3.

46 Bird RP. Role of aberrant crypt foci in understanding the pathogenesis of colon cancer. Cancer Lett 1995;93:55-71.

47 Jen J, Kim H, Piantadosi S, et al. Allelic loss of chromosome $18 \mathrm{q}$ and prognosis in colorectal cancer. $N$ Engl f Med 1994;331:213-21.

48 Vogelstein BV, Fearon ER, Hamilton SR, et al. Genetic alterations during colorectal tumour development. $N$ Engl F Med 1988;319:525-32.

49 Kinzler KW, Nilbert MC, Vogelstein B, et al. Identification of a gene located at chromosome $5 \mathrm{q} 21$ that is mutated in colorectal cancers. Science 1991;251:1366-70.

50 Curtis LJ, Bubb VJ, Gledhill S, et al. Loss of heterozygosity of MCC is not associated with mutation of the retained allele in sporadic colorectal cancer. Hum Mol Genet 1994;3 $443-6$.
51 Hahn SA, Hoque AT, Moskaluk CA, et al. Homozygous deletion map at $18 \mathrm{q} 21.1$ in pancreatic cancer. Cancer Res 1996;56:490-4

52 Lane DP. Cancer. p53, guardian of the genome. Nature 992;358:15-16.

53 Donehower LA, Bradley A. The tumor suppressor p53. Biochim Biophys Acta 1993;1155:181-205.

54 Carder P, Wyllie AH, Purdie CA, et al. Stabilised p 53 facilitates aneuploid clonal divergence in colorectal cancer. Oncogene 1993;8:1397-401.

55 Krawczak M, Smith SB, Schmidtke J, et al. Somatic spectrum of cancer associated single basepair substitutions in the p53 gene is determined mainly by endogenous mechanisms of mutation and by selection. Hum Mutat 1995;5:48-57.

56 Baker SJ, Preisinger AC, Jessup JM, et al. p53 gene mutations occur in combination with $17 \mathrm{p}$ allelic deletions as late events in colorectal tumorigenesis. Cancer Res 1990; 50:7717-22

57 Cunningham J, Lust JA, Schaid DJ, et al. Expression of p53 and allelic loss in colorectal carcinoma. Cancer Res 992;52:1974-80

58 Kawasaki Y, Monden T, Morimoto H, et al. Immunohistochemical study of p53 expression in microwave fixed, paraffin embedded sections of colorectal carcinoma and adenoma. Am f Clin Pathol 1992;97:244-9.

59 Ohta $\mathrm{M}$, Inoue $\mathrm{H}$, Cotticelli MG, et al. The FHIT gene, spanning the chromosome 3 p14.2 fragile site and renal carcinoma associated t $(3,8)$ breakpoint, is abnormal in digestive tract cancers. Cell 1996;84:587-97.

60 Okamoto A, Demetrick DJ, Spillare EA, et al. Mutations and altered expression of p16INK4 in human cancer. Proc Natl Acad Sci U S A 1994;91:11045-9.

61 Herman JG, Merlo A, Mao L, et al. Inactivation of the CDKN2/p16/MTS1 gene is frequently associated with a berrant DNA methylation in all common human cancers. Cancer Res 1995;55:4525-30.

62 Gonzalez ZM, Bender CM, Yang AS, et al. Methylation of the 5 'CpG island of the p16/CDKN2 tumor suppressor ene in normal and transformed human tissues correlates with gene silencing. Cancer Res 1995;55:4531-5.

63 Leister I, Weith A, Bruderlein S, et al. Human colorectal cancer: high frequency of deletions at chromosome $1 \mathrm{p} 35$. Cancer Res 1990;50:7232-5.

64 Praml C, Finke LH, Herfarth C, et al. Deletion mapping defines different regions in $1 \mathrm{p} 34.2$ pter that may harbor genetic information related to human colorectal cancer. Oncogene 1995;11:1357-62.

65 Wildrick D, Alfaro S, Gope R, et al. A study of chromosome 6 allele loss in human colorectal carcinomas. Anticancer $R$ es 1992;12:1717-19.

66 Fujiwara Y, Emi $M$, Ohata $H$, et al. Evidence for the presence of two tumor suppressor genes on chromosome presence of two tumor suppressor genes on chromosome

67 Cunningham C, Dunlop MG, Wyllie AH, et al. Deletion mapping in colorectal cancer of a putative tumour suppressor gene in $8 \mathrm{p} 22 \mathrm{p} 21.3$. Oncogene 1993;8:1391-6.

68 Young J, Leggett B, Ward M, et al. Frequent loss of heterozygosity on chromosome 14 occurs in advanced colorectal carcinomas. Oncogene 1993;8:671-5.

69 Yana I, Kurahashi H, Nakamori S, et al. Frequent loss of heterozygosity at telomeric loci on $22 \mathrm{q}$ in sporadic colorectal cancers. Int f Cancer 1995;60:174-7.

70 Liu B, Parsons R, Papadopoulos N, et al. Analysis of mismatch repair genes in hereditary non polyposis colorectal cancer patients. Nat Med 1996;2:169-74.

71 Kim H, Jen J, Vogelstein B, et al. Clinical and pathological characteristics of sporadic colorectal carcinomas with DNA replication errors in microsatellite sequences. $A m 7$ Pathol 1994;145:148-56.

72 Young J, Leggett B, Gustafson C, et al. Genomic instability occurs in colorectal carcinomas but not in adenomas. Hum Mutat 1993:2:351-4.

73 Ilyas M, Tomlinson IPM, Novelli MR, et al. Clinico pathoogical features and p53 expression in left sided sporadic colorectal cancers with and without microsatellite instability. F Pathol 1996;179:370-5.

74 da Costa LT, Liu B, El Deiry WS, et al. Polymerase and variants in RER colorectal tumours. Nat Genet 1995;9:1011 .

75 Linn SC, Giaccone G. MDR1/P glycoprotein expression in colorectal cancer. Eur $\mathcal{F}$ Cancer 1995;31A:1291-4.

76 Nuovo GJ. In situ PCR: protocols and applications. PCR Methods Appl 1995;4:S151-67.

77 Pignatelli M, Liu D, Nasim MM, et al. Morphoregulatory activities of $\mathrm{E}$ cadherin and beta 1 integrins in colorectal tumour cells. Br 7 Cancer 1992;66:629-34.

78 De Bruin PAF, Griffioen G, Verspaget HW, et al. Plasminogen activator profiles in neoplastic tissues of the human colon. Cancer Res 1988;48:4520-4.

79 Sier CFM, Vloedgraven HJM, Griffioen G, et al. Plasminogen activators and inhibitor type 1 in neoplastic colonic tissue from patients with familial adenomatous polyposis. $\mathrm{Br}$ f Cancer 1995;71:393-6.

80 MacDonald NJ, de la Rosa A, Steeg PS. The potential roles of nm23 in cancer metastasis and cellular differentiation. Eur F Cancer 1995;31A:1096-100.

81 Martinez JA, Prevot S, Nordlinger B, et al. Overexpression of $\mathrm{nm} 23 \mathrm{H} 1$ and $\mathrm{nm} 23 \mathrm{H} 2$ genes in colorectal carcinomas and loss of $n m 23 \mathrm{H} 1$ expression in advanced tumour stages. Gut 1995;37:712-20.

82 Iacopetta B, DiGrandi S, Dix B, et al. Loss of heterozygosity of tumour suppressor gene loci in human colorectal carcinoma. Eur $\mathcal{F}$ Cancer 1994;30A:664-70. 
83 Cawkwell L, Lewis FA, Quirke P. Frequency of allele loss of DCC, p53, RBI, WT1, NF1, NM23 and APC/MCC in colorectal cancer assayed by fluorescent multiplex polymerase chain reaction. Br f Cancer 1994;70:813-18.

84 Campo E, Miquel R, Jares P, et al. Prognostic significance of the loss of heterozygosity of $\mathrm{nm} 23 \mathrm{~h} 1$ and p 53 genes in human colorectal carcinomas. Cancer 1994;73:2913-21.

85 Ichikawa W. Positive relationship between expression of CD44 and hepatic met

86 Vogelstein B, Fearon ER, Kern SE, et al. Allelotype of colorectal carcinomas. Science 1989;244:207-11.

87 Gerdes $\mathrm{H}$, Chen $\mathrm{O}$, Elahi $\mathrm{AH}$, et al. Recurrent deletion involving chromosomes 1, 5, 17, and 18 in colorectal carcinoma: possible role in biological and clinical behavior of tumors. Anticancer Res 1995;15:13-24.

88 Laurent-Puig P, Olschwang S, Delattre O, et al. Survival and acquired genetic alterations in colorectal cancer. Gastroenacquired genetic alteration

89 Cohn KH, Ornstein DL, Wang F, et al. The significance of allelic deletions and aneuploidy in colorectal carcinoma. Results of a 5 year follow up study. Cancer 1997;79:233-44.

$90 \mathrm{Kern}$ SE, Fearon ER, Tersmette KW, et al. $7 A M A$ 1989;261:3099-103.

91 Ogunbiyi OA, Goodfellow PJ, Herfarth K, et al. Confirmaprognostic indicator. F Clin Oncol 1998;16:427-33.

92 Carethers JM, Hawn MT, Greenson JK, et al. Prognostic significance of allelic lost at chromosome 18q21 for stage II colorectal cancer. Gastroenterology 1998;114:1188-95.

93 Martinez-Lopez E, Abad A, Font A, et al. Allelic loss on chromosome $18 \mathrm{q}$ as a prognostic marker in stage II colorectal cancer. Gastroenterology 1998;114:1180-7.

94 Khine K, Smith DR, Goh HS. High frequency of allelic deletion on chromosome $17 \mathrm{p}$ in advanced colorectal deletion on chromosome 17p

95 Purdie CA, Piris J, Bird CC, et al. 17q allele loss is associated with lymph node metastasis in locally agressive human with lymph node metastasis in locally aggre
colorectal cancer. $\mathcal{F}$ Pathol 1995;175:297-302.

96 Berney CR, Fisher RJ, Yang J, et al. Genomic alterations (LOH, MI) on chromosome 17q21-23 and prognosis of sporadic colorectal cancer. Int $\mathcal{F}$ Cancer 2000;89:1-5

97 Kelemen PR, Yaremko ML, Kim AH, et al. Loss of heterozygosity in $8 \mathrm{p}$ is associated with microinvasion in colorecta carcinoma. Genes Chromosomes Cancer 1994;11:195-8.

98 Ogunbiyi OA, Goodfellow PJ, Gagliardi G, et al. Prognostic value of chromosome $1 \mathrm{p}$ allelic loss in colon cancer. Gastroenterology 1997;113:761-6.

99 Gustafson CE, Young J, Leggett B, et al. Loss of heterozygosity on the long arm of chromosome 11 in colorectal tumours. Br f Cancer 1994;70:395-7.

100 Arribas R, Ribas M, Risques RA, et al. Prospective assessment of allelic losses at $4 \mathrm{p} 14-16$ in colorectal cancer: two mutational patterns and a locus associated with poorer surmutational patterns and a locus associte
vival. Clin Cancer Res 1999;5:3454-9.

101 Finkelstein SD, Sayegh R, Christensen S, et al. Genotypic classification of colorectal adenocarcinoma. Biologic behavior correlates with $\mathrm{K}$ ras 2 mutation type. Cancer 1993 71:3827-38.

102 Moerkerk P, Arends JW, van Driel M, et al. Type and number of Ki ras point mutations relate to stage of human colorectal cancer. Cancer Res 1994;54:3376-8.

103 Span M, Moerkerk PT, De Goeij AF, et al. A detailed analysis of $\mathrm{K}$ ras point mutations in relation to tumor progression and survival in colorectal cancer patients. Int $\mathcal{F}$ Cancer 1996;69:241-5.

104 Kastrinakis WV, Ramchurren N, Maggard M, et al. K ras status does not predict successful hepatic resection of colorectal cancer metastasis. Arch Surg 1995;130:9-14.

105 Benhattar J, Losi L, Chaubert P, et al. Prognostic significance of $\mathrm{K}$ ras mutations in colorectal carcinoma. significance of K ras mutations in
Gastroenterology 1993;104:1044-8.

106 Pricolo VE, Finkelstein SD, Wu TT, et al. Prognostic value of p53 and $K$ ras 2 mutational analysis in stage III carcinoma of the colon. Am F Surg 1996;171:41-6.

107 Andreyev HJ, Norman AR, Cunningham D, et al. Kirsten ras mutations in patients with colorectal cancer: the multicenter "RASCAL" study. F Natl Cancer Inst 1998;90:67584.

108 Seeburg PH, Colby WW, Capon DJ, et al. Biological properties of human c Ha ras 1 genes mutated at codon 12 . Nature 1984;312:71-5.

109 Bos JL, Toksoz D, Marshall CJ, et al. Amino acid substitutions at codon 13 of the $\mathrm{N}$ ras oncogene in human acute myeloid leukaemia. Nature 1985;315:726-30.

110 Fasano O, Aldrich T, Tamanoi F, et al. Analysis of the transforming potential of the human $\mathrm{H}$ ras gene by random mutagenesis. Proc

111 Manne V, Bekesi E, Kung HF. Ha ras proteins exhibit GTPase activity: point mutations that activate $\mathrm{Ha}$ ras gene products result in decreased GTPase activity. Proc Natl Acad Sci U S A 1985;82:376-80.

112 Der CJ, Finkel T, Cooper GM. Biological and biochemical properties of human rasH genes mutated at codon 61 . Cell 1986;44:167-76.

113 McGrath JP, Capon DJ, Goeddel DV, et al. Comparative biochemical properties of normal and activated human ras p21 protein. Nature 1984;310:644-9.

114 Shibata D, Reale MA, Lavin P, et al. The DCC protein and prognosis in colorectal cancer. $N$ Engl f Med 1996;335: 1727-32.

115 Saito M, Yamaguchi A, Goi T, et al. Expression of DCC protein in colorectal tumors and its relationship to tum progression and metastasis. Oncology 1999;56:134-41.
116 Sankila R, Aaltonen LA, Jarvinen HJ, et al. Better survival rates in patients with MLH1-associated hereditary colorecrates in patients with MLH1-associated here

117 Fujita S, Moriya Y, Sugihara K, et al. Prognosis of hereditary nonpolyposis colorectal cancer (HNPCC) and the role of Japanese criteria for HNPCC. Ipn f Clin Oncol 1996;26: $351-5$.

118 Bubb VJ, Curtis LJ, Cunningham C, et al. Microsatellite instability and the role of hMSH2 in sporadic colorectal cancer. Oncogene 1996;12:2641-9.

119 Massa MJ, Iniesta P, Gonzalez-Quevedo R, et al. Differential prognosis of replication error phenotype and loss of heterozygosity in sporadic colorectal cancer. Eur $\mathcal{F}$ Cancer 1999;35:1676-82

120 Gryfe R, Kim H, Hsieh ET, et al. Tumor microsatellite instability and clinical outcome in young patients with colorectal cancer. N Engl f Med 2000;342:69-77.

121 Johannsdottir JT, Bergthorsson JT, Gretarsdottir S, et al. Replication error in colorectal carcinoma: association with loss of heterozygosity at mismatch repair clinicopathological variables. Anticancer Res 1999;19:18216.

122 Jernvall P, Makinen MJ, Karttunen TJ, et al. Microsatellite instability: impact on cancer progression in proximal and distal colorectal cancers. Eur f Cancer 1999;35:197-201.

23 Elsaleh H, Powell B, Soontrapornchai P, et al. p53 gene mutation, microsatellite instability and adjuvant chemotherapy: impact on survival of 388 patients with Dukes' C colon carcinoma. Oncology 2000;58:52-9.

124 Wright CM, Dent OF, Barker M, et al. Prognostic significance of extensive microsatellite instability in sporadic clinicopathological stage C colorectal cancer. Br f Surg 2000;87:1197-202.

125 Hemminki A, Mecklin JP, Jarvinen H, et al. Microsatellite instability is a favorable prognostic indicator in patients with colorectal cancer receiving chemotherapy. Gastroenterology 2000;119:921-8.

126 Salahshor S, Kressner U, Fischer H, et al. Microsatellite instability in sporadic colorectal cancer is not an independnt prognostic factor. Br f Cancer 1999;81:190-3.

27 Remvikos Y, Tominaga O, Hammel P, et al. Increased p53 protein content of colorectal tumours correlates with poor survival. Br f Cancer 1992;66:758-64.

128 Kressner U, Lindmark G, Gerdin B, et al. Immunohistological p53 staining is of limited value in the staging and prognostic prediction of colorectal cancer. Anticancer Res 1996;16:951-7.

129 Diez M, Enriquez JM, Camunas J, et al. Prediction of recurrence in B C stages of colorectal cancer by p53 nuclear overexpression in comparison with standard pathological features. Eur 7 Surg Oncol 1995;21:635-9.

130 Grewal H, Guillem JG, Klimstra DS, et al. p53 nuclear overexpression may not be an independent prognostic marker in early colorectal cancer. Dis Colon Rectum 1995;38:1176-81.

131 Lazaris AC, Theodoropoulos GE, Anastassopoulos P, et al. Prognostic significance of p53 and c erbB 2 immunohistochemical evaluation in colorectal adenocarcinoma. Histol Histopathol 1995;3:661-8.

132 Houbiers JG, van der Burg SH, van de Watering LM, et al. Antibodies against p53 are associated with poor prognosis of colorectal cancer. Br F Cancer 1995;72:637-41.

133 Tomoda H, Kakeji Y. Immunohistochemical analysis of p53 in colorectal cancer regarding clinicopathological correlation and prognostic significance. F Surg Oncol 1995;58: $125-8$.

134 Morrin M, Kelly M, Barrett N, et al. Mutations of Ki ras and p53 genes in colorectal cancer and their prognostic significance. Gut 1994;35:1627-31.

135 Zeng ZS, Sarkis AS, Zhang ZF, et al. p53 nuclear overexpression: an independent predictor of survival in ymph node positive colorectal cancer patients. f Clin Oncol 1994;12:2043-50.

136 Tanaka M, Omura K, Watanabe Y, et al. Prognostic factors of colorectal cancer: $\mathrm{K}$ ras mutation, overexpression of the 553 protein, and cell proliferative activity. F Surg Oncol 1994;57:57-64.

137 Suzuki H, Matsumoto K, Koide A, et al. Correlation of p53 with the clinicopathologic features and prognosis of colorectal adenocarcinoma. Surg Today 1994;24:85-7.

138 Nathanson SD, Linden MD, Tender P, et al. Relationship among $\mathrm{p} 53$, stage, and prognosis

Colon Rectum 1994;37:527-34.

9 Bell SM, Scott N, Cross D, Sagar P, et al. Prognostic value of $\mathrm{p} 53$ overexpression and $\mathrm{c} \mathrm{Ki}$ ras gene mutations in colorectal cancer. Gastroenterology 1993;104:57-64.

140 Yamaguchi A, Kurosaka Y, Fushida S, et al. Expression of p53 protein in colorectal cancer and its relationship to hort term prognosis. Cancer 1992;70:2778-84.

141 Goh HS, Yao J, Smith DR. p53 point mutation and survival in colorectal cancer patients. Cancer Res 1995;55: 5217-21

142 Hamelin R, Laurent Puig P, Olschwang S, et al. Association of p53 mutations with short survival in colorectal cancer. Gastroenterology 1994;106:42-8.

143 Bertorelle R, Esposito G, Del Mistro A, et al. Association of p53 gene and protein alterations with metastases in colorectal cancer. Am f Surg Pathol 1995;19:463-71.

144 Kastrinakis WV, Ramchurren N, Rieger KM, et al. Increased incidence of p53 mutations is associated with hepatic metastasis in colorectal neoplastic progression. Oncogene 1995;11:647-52.

145 Goh HS, Chan CS, Khine K, et al. p53 and behaviour of colorectal cancer. Lancet 1994;344:233-4. 
146 Bosari S, Viale G, Roncalli M, et al. p53 gene mutations, p53 protein accumulation and compartmentalization in

47 Smith DR, Ji CY, Goh HS. Prognostic significance of p53 overexpression and mutation in colorectal adenocarcinomas. Br f Cancer 1996;74:216-23.

148 Steeg PS, Abrams JS. Cancer prognostics: past, present and p27. Nat Med 1997;3:152-4

149 Loda M, Cukor B, Tam SW, et al. Increased proteasome dependent degradation of the cyclin dependent kinase inhibitor p27 in aggressive colorectal carcinomas. Nat Med 1997;3:231-4.

150 Tenjo T, Toyoda M, Okuda J, et al. Prognostic significance of p27 (kip1) protein expression and spontaneous apoptosis in patients with colorectal adenocarcinomas. Oncology 2000;58:45-51.

151 Liu DF, Ferguson K, Cooper GS, et al. p27 cell-cycle inhibitor is inversely correlated with lymph node metastases in right-sided colon cancer. F Clin Lab Anal 1999;13: 291-5.

152 Palmqvist R, Stenling R, Oberg A, et al. Prognostic significance of p27 (Kip1) expression in colorectal cancer: a clinico-pathological characterization. f P Pathol 1999;188: clinico-path.

153 Lindforss U, Fredholm H, Papadogiannakis N, et al. Allelic loss is heterogeneous throughout the tumor in colorectal carcinoma. Cancer 2000;88:2661-7.

\section{1st Asia Pacific Forum on Quality Improvement in Health Care}

\section{Three day conference}

\section{Wednesday 19 to Friday 21 September 2001 Sydney, Australia}

We are delighted to announce this forthcoming conference in Sydney. Authors are invited to submit papers (call for papers closes on Friday 6 April), and delegate enquiries are welcome. The themes of the Forum are:

- Improving patient safety

- Leadership for improvement

- Consumers driving change

- Building capacity for change: measurement, education and human resources

- The context: incentives and barriers for change

- Improving health systems

- The evidence and scientific basis for quality improvement.

Presented to you by the BMJ Publishing Group (London, UK) and Institute for Healthcare Improvement (Boston, USA), with the support of the the Commonwealth Department of Health and Aged Care (Australia), Safety and Quality Council (Australia), NSW Health (Australia), and Ministry of Health (New Zealand).

For more information contact: quality@bma.org.uk or fax +44 (0)20 73836869 